\title{
Advancing Sustainable Development Goals (SDGs): An Analysis of How Non- Financial Services of Microfinance Insitutions Facilitate Human Capital Development of Clients in Ghana
}

\author{
Ernestina Fredua Antoh ${ }^{1} \&$ Albert A Arhin ${ }^{1}$ \\ ${ }^{1}$ Bureau of Integrated Rural Development (BIRD), Kwame Nkrumah University of Science and Technology, \\ Ghana
}

Correspondence: Albert A Arhin, Bureau of Integrated Rural Development (BIRD), Kwame Nkrumah University of Science and Technology, University Post Office, Kumasi, Ghana. Tel: 233-5-5593-9173. E-mail: aaarhin@knust.edu.gh

Received: February 19, 2018

Accepted: April 14, $2018 \quad$ Online Published: July 29, 2018

doi:10.5539/jsd.v11n4p257

URL: https://doi.org/10.5539/jsd.v11n4p257

\begin{abstract}
In 2015, the United Nations General Assembly adopted the 2030 Agenda for Sustainable Development, together with seventeen goals that are collectively called the Sustainable Development Goals (SDGs). This study examined the effects of non-financial microfinance services on human capital development of clients and discusses its implications on the achievement of the Sustainable Development Goals. The case is drawn from Sinapi Aba Trust (SAT), which is a microfinance institution of Ghana. Primary data were collected from 361 clients in seven districts of the Ashanti Region, Ghana. The results of the ordinary least square (OLS) regression showed that non-financial services offered by SAT had positive significance on human capital development of the clients. This finding shows how additional services from microfinance institution could help clients to maximise the value of loans offered to support income-generating economic activities. For clients, the study also draws attention to the need for them to take non-financial services offered by microfinance institutions seriously to improve on their own human capital development in the context of the SDGs.
\end{abstract}

Keywords: microfinance, human capital development, SDGs, Ghana

\section{Introduction}

In 2015, the United Nations General Assembly adopted the 2030 Agenda for Sustainable Development, which comprise seventeen goals that are collectively called the Sustainable Development Goals (SDGs). Building on the erstwhile Millenium Development Goals (MDGs), the SDGs seek to among other things end poverty, ensure that people across every part of the world enjoy peace and prosperity and protect the planet. In the context of the SDGs, microfinance schemes are gaining traction across the globe as a policy tool for facilitating economic empowerment and employment creation for millions of people (Mosley and Roch, 2004; Afrane, 2002). As a financial intermediation tool, the traditional role of microfinance has been to target and to provide micro loans to people who are generally not served by the mainstream financial institutions due to their inability to produce collateral. This reflects microfinance's underlying philosophy of providing affordable access of poor families to financial services for improved incomes and livelihoods (Yunus, 2003). Mahjabeen (2008) argues that most of the poor households and individuals served by microfinance institutions are low-income and middle-income people who live mainly in developing countries. This group of people obtain loans, either in their own capacities or through membership to a group, to undertake business activities, which raise income and consumption levels of families, reduce income inequality and enhance social welfare.

The influence of microfinance services on human capital development has become a subject of interest over the past recent years - and especially in the context of the SDGs (Consultative Group Assistance to the Poor, 2016). On one hand, some have shown that microfinance have improved human capital development through increased access of clients to socio-economic facilities such as education, health and nutrition (Khavul, 2010; Odell, 2010). In contrast, others (e.g. Melzer, 2011) contest the acclaimed positive impacts of microfinance and persuasively argue that microfinance does not reach or benefit the poor and even if it does it rather destroys their resourcefulness due to repayment difficulties. Over the years, the services that are offered to clients of 
microfinance have expanded in many directions (Hamada, 2010). Aside, the traditional focus on provision of micro loans and savings for income-generating activities, Microfinance Institutions (MFI) also provide several non-financial services to clients.

While the public interests in microfinance are growing, there is still limited understanding especially in Africa about the effect of microfinance schemes for the promotion of human capital development. Available studies that aim to link the effects of microfinance to clients' human capital development outcomes are narrow and inconclusive (e.g. Fischer and Ghatak, 2010). Even crucially, most studies focus largely on the effects of the core financial services (i.e. loans for income-generating activities). As a result, the effects of non-financial services of microfinance schemes on human capital development are under reported in the literature. This present article fills some of these limitations in the literature.

The main objectives of this paper are two-folds. First, it seeks to identify some of the non-financial services that MFIs offer to clients. Second, it empirically examines the extent to which the non-financial microfinance services affect human capital development of clients. The paper then discusses the implications of the findings on the human capital development in the context of th operationalization of the Sustainable Development Goals. The paper uses a long-term research and the experience of the Sinapi Aba Trust (SAT) which is a microfinance institution in Ghana to advance its argument. Although the term human capital is a contested concept, it is understood to involve the skills and knowledge people possess that empower them to create value in the global economic system (Schultz, 1961). This study focuses on non-formal education, formal education of children and health of clients as the main indicators for human capital development. For the purpose of this article, we have also defined non-financial microfinance services to include all services other than provision of loans for income-generating activities that are offered by MFIs to clients. The study is significant for at least three reasons. First, it makes an empirical contribution to the extent to which non-financial services offered by microfinance institutions improve human capital development. Second, it provides information to microfinance institutions about how they can design different schemes that will help clients to maximise the value of the loans offered for income-generating activities. Third, the effects of microfinance on human capital development of clients is also an important measure for understanding some of the pathways through which microfinance contribute to empowerment and poverty reduction. The article has been structured as follows. Section 2 presents a brief profile of Ghana and the Sinapi Aba Trust, the microfinance institution studied. Section 3 discusses the literature and theoretical perspectives that informed the study. The succeeding section (i.e. section 4) presents the methodology and followed by the results and discussions of the findings (section 5). The last section provides the conclusion and highlights the policy implications of the study.

\subsection{Brief Profile of Ghana and the Sinapi Aba Trust}

Ghana, located in West Africa, has an estimated population of 26 million (Ghana Statistical Service, 2012). Since the 1990s, Ghana has made significant progress in addressing poverty. According to the 2015 Ghana's Millennium Development Goals Report, the proportion of the population living below poverty declined from 51.7 percent in 1991 to 28.5 percent in 2006 whereas the proportion in extreme poverty dropped from 36.5 percent in 1991 to 18.2 percent in 2006 (Republic of Ghana and UNDP, 2015). Annual Gross National Income per capita was around US\$1,550 in 2012.

Although over $70 \%$ of the settlements in Ghana are rural areas where agriculture is the predominant source of employment, there are more people living in urban areas than in rural areas (Ghana Statistical Service, 2014). More than half $(67.9 \%)$ of the working age population of the country are in employment (Ghana Statistical Service, 2016). However, available data suggests that only 1 out of 10 employed people is engaged in a formal sector employment whereas about 9 in every 10 people are employed in the informal sector (Ghana Statistical Service, 2016). The informal sector is made up of small to medium-scale businesses consisting of producers, retail traders and wholesaleand service providers comprising contributing family workers, casual wage workers, home-based workers and street vendors, among others. Most of these are largely self-employed persons. The informal sector serves as an essential clientele base for MFIs in Ghana.

The microfinance sector in Ghana has evolved to its present state through series of policies, programmes and interventions in the financial sector undertaken by the government since independence from British colonial powers in 1957. Among these interventions include subsidized credits in the 1950s, the establishment of the Agricultural Development Bank in the mid-1960s and creation of Rural and Community banks in the 1970s. Since the 1980s, different interventions were also undertaken including a policy directive for commercial banks to set aside at least 20 percent of lending portfolio to agriculture and small-scale industries. One effect of the series of policy interventions included an evolution of various non-formal financial institutions that emerged in 
parallel to the formal institutions to provide credit facilities to sections of the population. The Sinapi Aba Trust (SAT) evolved from these non-formal financial institutions. Since the 1990s, past and present governments have focused on microfinance as a public policy tool for improving human capital development and lifting many people out of poverty. This policy approach stemmed, in part from, the recognition of the negative influence of poverty on human capital development (National Development Planning Commission NDPC, 2010). Accordingly, a series of programmes such as the Micro and Small Loans Centre (MASLOC) scheme and the creation of enabling environment for the growth of microfinance schemes have been central under Ghana's growth and medium-term development agenda for the past decade (Government of Ghana, 2010; NDPC, 2008).

The Sinapi Aba Trust (SAT), is a Non-Governmental Christian Microfinance Institution in Ghana with an affiliation to Opportunity International (OI). SAT was established in 1994 as a company limited by guarantee to extend loan facilities to businesses owned by the low-income population. Loans are offered to both individuals as well as groups. Sinapi Aba is the local translation of the biblical (Mathew 13: 31-32) mustard seed which informed SAT's mission to serve as a "Mustard Seed" to create opportunities for enterprise development and income generation to the economically disadvantaged in the Ghanaian society to transform their lives (SAT, 1996).

Starting from the Ashanti Region, SAT has gradually spread to other geographical parts in Ghana, with impressive growing clients' strength and among the leading MFIs in Ghana. Data available for 2010 suggest that, SAT had a borrower population of 99,906 - and it continues to grow. In the Ashanti Region where this study is focused, SAT's microfinance activities had covered seven districts at the time of the study. These were the Kumasi Metropolis, Obuasi, Mampong, Asante Akyemand Offinso, municipalities and Atwima Nwabiagya and Ejura Sekyedumase districts. Clients' livelihood activities cover small-scale manufacturing, food and agriculture, trade and services.

\section{Review of literature}

\subsection{Understanding Microfinance and Human Capital Development}

Conventionally, microfinance schemes have focused on providing credit to low income groups in diverse settings for income-generating activities (Antoh et al., 2014). However, microfinance schemes are diverse in form. Schemes typically differ by legal status and ownership (private, cooperative, hybrid), sources of funds (member contributions or not), scale of operations (local, national, international), type of financial services they provide (financial and non-financial services) among others (Matin, Hulme, \& Rutherford, 1999). Diverse financial and non-financial services have been designed by microfinance institutions for raising human capital development and promoting sustainable development over the years (Antoh et al., 2014).

To understand the effects of non-financial services on human capital development of clients, the study drew extensively on financial intermediation and human capital theories. The theory of financial intermediation deals with how individuals and firms raise and distribute funds for development. The theory assumes that access to finance plays a key role in the ability to increase income generation and employment opportunities, which ultimately lead to increased household incomes and assets. Claessens and Tzioumis (2006) have advanced the significance of financial intermediation and affirmed that the lack of it could present persistent income inequality or poverty traps, as well as lower growth.

Two main focus of the ever-growing literature on microfinance and financial intermediation could be distinguished. The first deals with the specific problems that poor people have in accessing financial intermediation services at an affordable cost, particularly due to their lack of collateral (Yunus, 1999). The second aspect of the literature explores the impact assessment of microfinance on households, socio-economic groups, enterprises and individuals (Duvendack et al., 2011). As emphasised in section 1, a characteristic of the growing literature has been the absence of the impact of the non-financial services to programme outcomes particularly on human capital development.

The theory of human capital development is rooted in the field of macroeconomic development theory (Schultz, 1993). Human capital is about the "the knowledge, skills, competencies, and attributes embodied in individuals that facilitate the creation of personal, social and economic well-being" (Organization for Economic Co-Operation and Development or OECD, 2001: 18). In other words, human capital comprises the knowledge, skills, attitude, ability and behaviour embedded in an individual (Afrane, 2002; Beach, 2009). The theory of human capital development posits that investments such as education, training and health can be made in human beings to generate potential returns to the initial investment for improved productivity and socio-economic development (Langelett, 2002). By implication, the concept recognises human beings (and their capabilities) as an essential driver of development. The theory of human capital development is therefore important to the 
multi-dimensional perspective of poverty reduction and provides a basis for a positive relationship between human capital development and poverty reduction (Becker, 1964; Schultz, 1961).

\subsection{The SDGs Human Capital Development and Microfinance}

The SDGs consist of 17 goals and 169 targets that the member states of the United Nations have agreed to use to frame or guide their development agendas and political policies over the next 15 years (up to 2030) - so as to transform the world. The 17 Goals build on the Millennium Development Goals and cover areas such as poverty reduction, improved health, quality education, peace and justice, sustainable consumption, economic inequality, , among other priorities (see fig. 1)

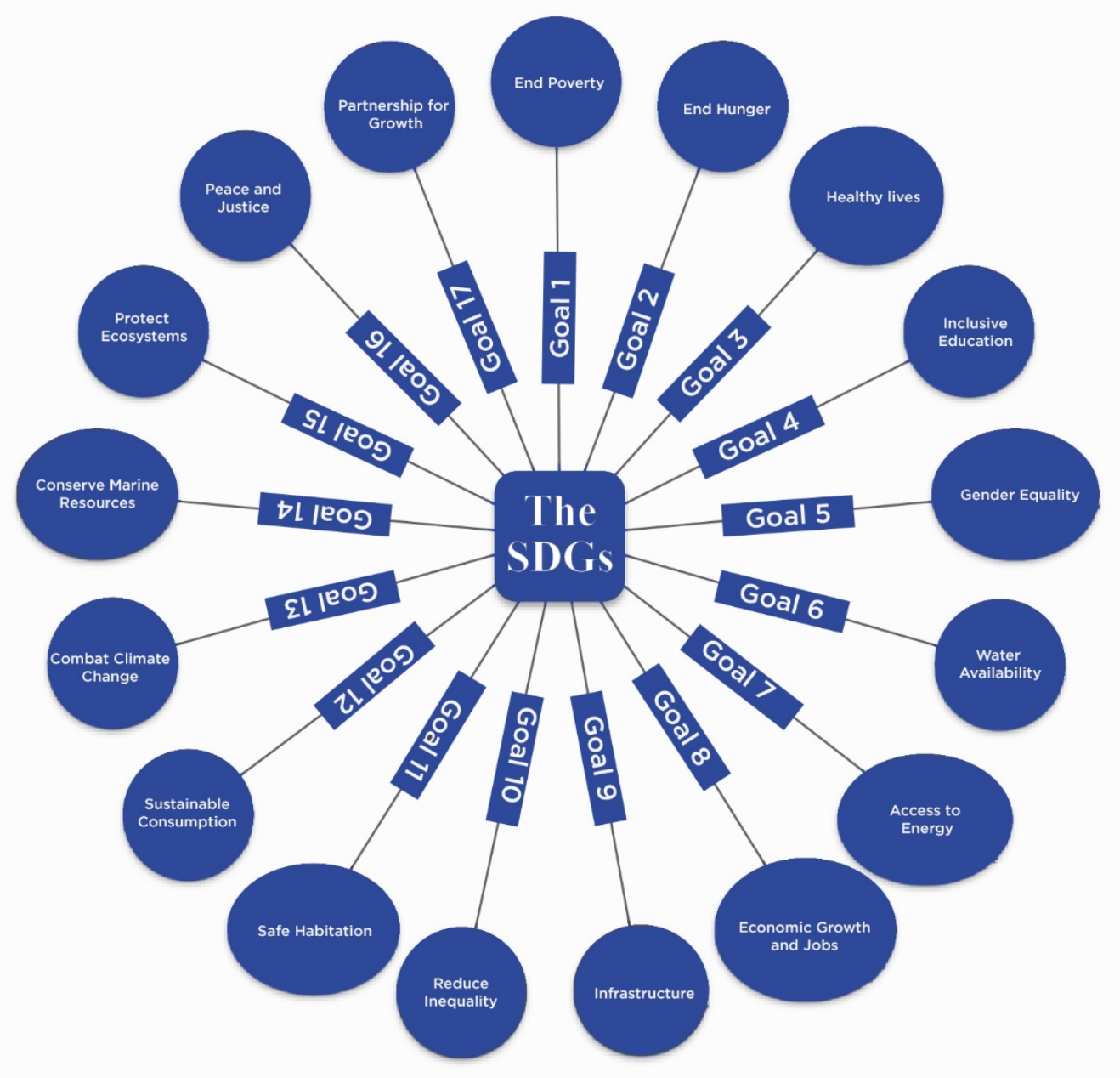

Figure 1. The UN SDGs

International development agencies such as the World Bank have argued that natural capital, physical capital and human capital are essential bedrocks for socio-economic growth and the attainment of sustainable development. Yet, the critical role of human capital in utilizing the other forms of capital to aid sustainable development has long been identified in the literature. As Harbison (1973) notes: "Human resource, not physical capital, not income or material resources constitute the ultimate basis for the wealth of nations. Capital and natural resources are passive factors of production, human beings are the active agents who accumulate capital; exploit natural resources; build social, economic and political organizations; and carry forward national development. Clearly, a nation which is unable to develop the skills and knowledge of its people and to utilize them effectively in the national economy will be unable to develop anything else". Harbison's argument points to the essential role of 
developing the skills, knowledge and capabilities of individuals within countries to facilitate the attainment of sustainable development. Microfinance has emerged as one of the important pathways to achieve this objective (Arouri et al., 2014; Consultative Group Assistance to the Poor, 2016). Several emerging researches are exploring the extent to which microfinance shape human capital development. Mosley and Roch (2004) concluded that increased expenditure on education remains an important pathway through which microcredit facilitates human capital. Further research has shown that microfinance insitutions enhance health to promote human capital development. One study in South Africa demonstrated that a comprehensive training and education programme by a microfinance institution was responsible for reducing the risk of physical and sexual abuse among clients by more than half (Pronyk, Hargreaves and Kim, 2006). In another experiment, Barnes, Gaile and Kimbombo (2001) reported from a study in Uganda that 32 percent of women who, by virtue of their membership to microfinance groups, received information and education on HIV/AIDS prevention attempted at least one prevention practice compared to 18 percent of non-clients'. Some other studies have also found positive health outcomes for microfinace services including reduced maternal mortality and improved child health (Leatherman and Dunford, 2010; De la Cruz et al., 2009). Thus, microfinance facilitates human capital development through avenues such as education and training. González-Vega and Romero (2003) contend that financial services facilitate consumption of basic needs such as food and health to obviate shocks. Microfinance also offers risk management opportunities for different socio-economic groups to reduce the vulnerability and risks associated with poverty (Adjei, Arun \& Hossain, 2009).

\section{Method}

This study employed both quantitative and qualitative methods and applied the descriptive and cross-sectional survey designs. Emerging literature suggests that integrated assessments that combine quantitative, qualitative and participatory methods help to overcome the inherent weaknesses that are found in exclusive applications of qualitative or quantitative methods (Kanbur \& Squire, 2001; Mayoux \& Chambers, 2005). In particular, the advantages of using a mixed methods approach include its ability to offset the weaknesses of both quantitative and qualitative research. Both primary and secondary data were collected. The primary data were collected from clients and officials of SAT.

In choosing respondents, the multi-stage sampling method was used. The targeted clients - the prime target of the study - were those who had been on a microfinance scheme of SAT for a minimum of two years with at least four loan cycles. These clients were expected to be adequately informed about the microfinance activities and reflect better on the information collected. The two-year duration was considered to be appropriate for beneficiaries to have experienced some form of effect on their business activities and lives for them to make meaningful participation in the process (Afrane, 2002; Maldonado, Gonzalez-Vega and Romero, 2003).

First, three out of the seven branches of SAT located in the Kumasi Metropolis, Ejura Sekyedumase and Obuasi Municipalities were purposively selected based on discussions with SAT officials. These branches were purposely selected because they were among where SAT's clients were largely concentrated. These three branches were also geographically positioned in the middle, southern and northern sectors of the Ashanti Region and respectively and differ in their levels of infrastructure, credit facilities, commercial and economic activities, making the areas representative of the survey population.

Available records showed that the client population of SAT for the three branches stood at 8734 at the time of the study. As such, we followed the sample size determination processes developed by Krejcie and Morgan (1970) (as cited in Sarantakos, 2005) to obtain an initial sample size of 368 beneficiaries or sample at a 95\% confidence interval. SAT had a list of beneficiaries of all the three branches and the next stage utilised these existing records from SAT to cluster the target beneficiaries to proportionally select the required sample size from each branch. This process allowed the characteristics of the population to occur in the sample and to facilitate analysis of data pertinent to each of the subgroups for internal validity and reliable conclusions. However, seven respondents could not honour the interviews. As such, 361 clients (comprising 268 females, 93 males) responded to the survey. In addition to the 361 clients, 13 senior officers of SAT comprising the Chief Executive Officer, Branch Managers and Financial Service Officers from Obuasi, Adum and Ejura branches were also interviewed as key informants. Other methods employed to gather qualitative data were focus group discussions, clients' work place observations and documents analysis. In analysing the data, descriptive statistics such as frequencies, percentages and tableswere used to interpret the information obtained.

In order to measure human capital development of clients, three variables or indicators were used. These were skills, enhanced knowledge and health power acquired by the clients after joining SAT. Principal Component Analysis (PCA) was adopted to measure these indicators of HCD. The average of the three of the variables that 
loaded significantly on the valid component was computed, after which its reliability was analysed. The reliability analysis using the Cronbach's Alpha showed a result of $89 \%$, which was high.

The ordinary least square (OLS) regression was then adopted to analyse the characteristics of the clients and the services of SAT that influenced the dependent variable: human capital development. The main explanatory variables or predictors contained in the analysis included personal characteristics such as age (AGE), sex(SEX), marital status (MSTATUS), number of children of SAT clients (NCHILDREN), level of education of client (EDUCATION) and the non-financial services provided by SAT (NONFINSERVE). The results of the analysis remain the attention of the next section.

\section{Results}

The results are presented in three subsections. The first subsection presents the socio-economic characteristics of the respondents. The second section presents the non-financial services offered by SAT while the last section presents the results about the effects of the non-financial services on human capital development.

\subsection{Socio-Demographic Characteristics of Respondents}

\subsubsection{Sex and Marital Status of Respondents}

Majority (74.2\%) of the beneficiary respondents were females (Table 1). This result corroborates the finding of Ghalib (2009) about how women that are engaged in informal activities tend to be the main beneficiaries of microfinance interventions. Table 1 further indicates that majority of the respondents $(77.3 \%)$ were married. The remaining respondents were single $(9.4 \%)$, widowed $(8.3 \%)$, divorced $(4.7 \%)$ or separated $(0.3 \%)$. . The essence of paying attention to marital status is due to its socio-cultural influence on gendered roles, tasks, and responsibilities as well as the management of household budget. The higher percentage of married clients could be due to the dominance of the active population making up the clients as presented in Table 1.

Table 1. Sex and marital status of respondents

\begin{tabular}{|c|c|c|c|c|c|c|c|c|c|c|c|c|}
\hline \multirow[b]{2}{*}{ Sex } & \multicolumn{2}{|c|}{ Single } & \multicolumn{2}{|c|}{ Married } & \multicolumn{2}{|c|}{ Divorced } & \multicolumn{2}{|c|}{ Widowed } & \multicolumn{2}{|c|}{ Separated } & \multicolumn{2}{|c|}{ Total } \\
\hline & No. & $\%$ & No. & $\%$ & No. & $\%$ & No. & $\%$ & No. & $\%$ & No. & $\%$ \\
\hline Female & 22 & 6.1 & 208 & 57.6 & 15 & 4.2 & 22 & 6.1 & 1 & .3 & 268 & 74.2 \\
\hline Male & 12 & 3.3 & 71 & 19.7 & 2 & .6 & 8 & 2.2 & 0 & .0 & 3 & 25.8 \\
\hline Total & 34 & 9.4 & 279 & 77.3 & 17 & 4.7 & 30 & 8.3 & 1 & .3 & 361 & 100.0 \\
\hline
\end{tabular}

Source: Field survey, 2012

\subsubsection{Number of Children of Respondents}

The number of children of the respondents varied from zero to ten. As table. 2 shows, 30.6 percent of respondents had five or more children, 23.5 percent of respondents had four while t 22.2 percent of the respondents had three. The results compare favourably with available national data, where average household size is recorded as is four (GSS, 2008). However, the result showed a negative skewness of -259 , which is an indication of an uneven distribution of number of children among respondents.

Table 2. Number of children of respondents

\begin{tabular}{ccc}
\hline NUMBER & FREQUENCY & PERCEEENT \\
\hline 0 & 14 & 3.9 \\
1 & 18 & 5.0 \\
2 & 54 & 15.0 \\
3 & 80 & 22.0 \\
4 & 85 & 23.5 \\
5 & 54 & 15.0 \\
$6+$ & 56 & 15.6 \\
Total & 361 & 100.0 \\
\hline
\end{tabular}

Source: Field survey, 2012 


\subsubsection{Age of Respondents}

The proportion of respondents who were aged between $21-30$ years were $4.2 \%, 31$ - 40 years was $30.7 \%, 41-50$ years was $40.2 \%, 51-60$ years was $21.3 \%$, and 60 years and above was $3.6 \%$. The mean age was 43 years. This means that farmers involved in cocoa production in themost clients were in the economically active population. The age of microfinance clients often influences the activities and decision making of clients. For instance, Gupta and Malhotra (2006) have observed that in many African contexts, age and sex could influence a person's decision-making position in the family. As the foregoing shows, there were more respondents in the economically active population (25-60 years) than those of that were above 60 years $(3.6 \%)$. .

Table 3. Age distribution of respondents

\begin{tabular}{ccc}
\hline AGE (YEARS) & FREQUENCY & PERCENT \\
\hline $21-30$ & 15 & 4.2 \\
$31-40$ & 111 & 30.7 \\
$41-50$ & 145 & 40.2 \\
$51-60$ & 77 & 21.3 \\
$60+$ & 13 & 3.6 \\
Total & 361 & 100.0 \\
\hline
\end{tabular}

Source: Field survey, 2012

\subsubsection{Level of Education of Respondents}

The descriptive statistics showed that majority of the respondents (51.4\%) had basic education, $15.2 \%$ had

education up to senior high school, $5.5 \%$ had technical, vocational and technical education, $10.2 \%$ had a post-secondary but non-tertiary education and $2.2 \%$ had tertiary education. Level of education of clients has been argued to be an essential factor that affects decision-making in businesses (Crisp and Turner, 2007). However, this study confirms the observation by Nader (2008) that microfinance clients are dominated by people with often low formal educational levels.

Table 4. Educational level of respondents

\begin{tabular}{ccc}
\hline Educational level & Frequency & Percent \\
\hline No formal education & 56 & 15.5 \\
Basic & 185 & 51.4 \\
Secondary & 55 & 15.2 \\
Comm/Tech/Voc & 20 & 5.5 \\
Post-secondary & 37 & 10.2 \\
University & 8 & 2.2 \\
\hline Total & 361 & 100.0 \\
\hline
\end{tabular}

Source: Field survey, 2012

\subsubsection{Microfinance Services Offered by SAT to Clients}

The analysis showed that besides the traditional role of providing micro loans for income-generating activities, SAT operates three other microfinance services to its clients. These are microcredit savings, remittance services, micro insurance and non-finance operations. This confirmed the observation that contemporary microfinance institutions are drifting from the traditional mission of providing micro loans and expanding to provide other non-financial services to their clients (Robinson, 2001).

The analyses of the data collected further show that the main non-financial services provided by SAT to its clients include entrepreneurial skill development, basic accounting principles and business records keeping. Moreover, 
SAT organises regular awareness creation to members on issues such as health, education and apprenticeship opportunities and spiritual growth. These additional and non-financial services were expected to work together with the core financial services provided to clients (i.e. loans and/or microsavings) to improve education, knowledge accumulation, skills and social networks to improve their standard of living. Fig. 1 provides examples of the additional and non-financial services that SAT had offered to the respondents at the time of the research.

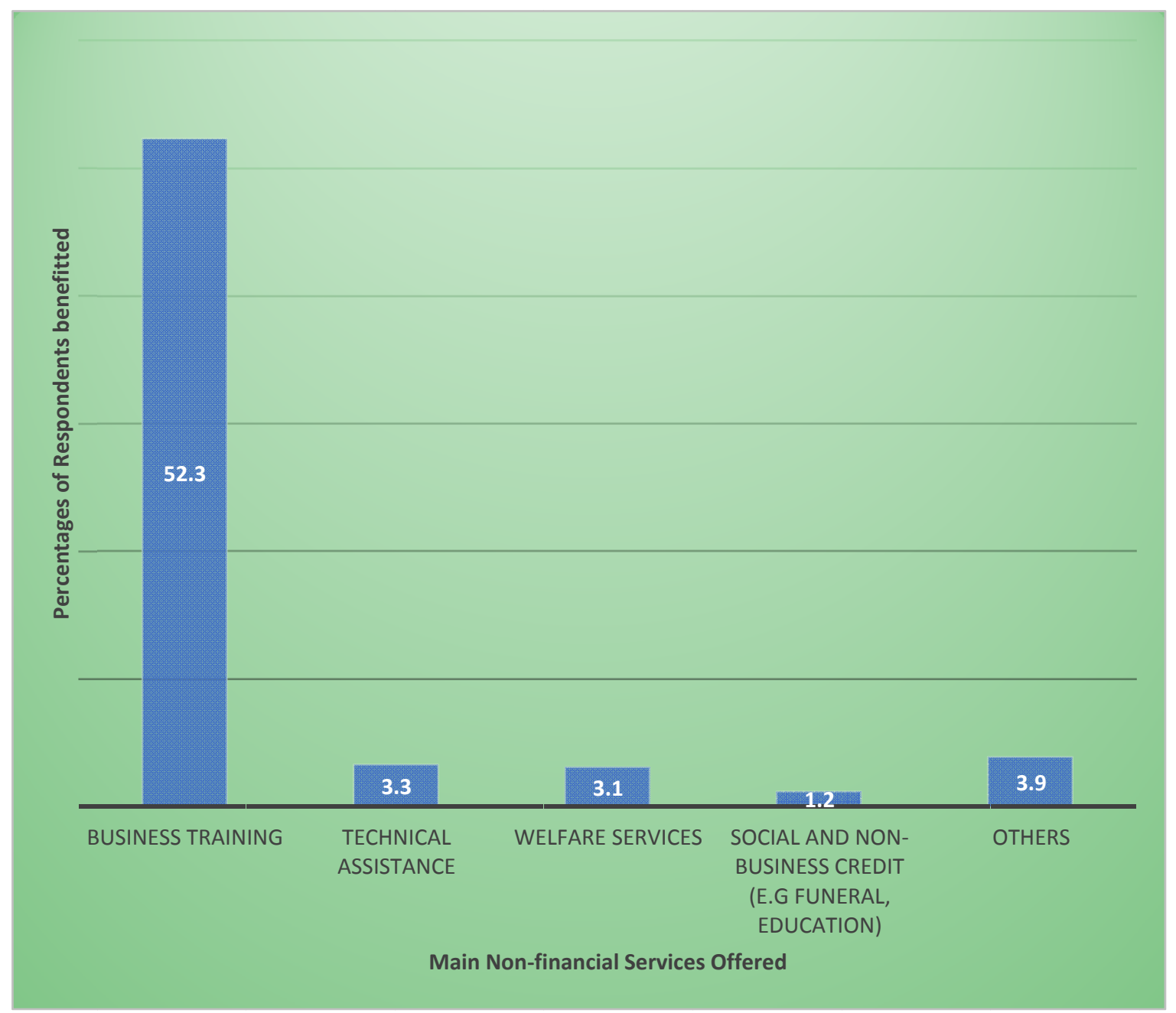

Source: Field survey, 2012

\subsubsection{Effects of Non-Financial Services on Human Capital Development}

The result of the effects of the non-financial services on human capital development has been presented as table 5. The analysis showed that the explanatory variables jointly and significantly explain human capital development of the clients. This is represented by the F-statistic of 12.453 at one percent significance level. The adjusted $R^{2}$ of 0.223 further shows that the explanatory variables were able to explain about $22 \%$ variation in the human capital development of clients. 
Table 5. Effects of beneficiary characteristics and non-financial services on human capital development

\begin{tabular}{llll}
\hline VARIABLE & COEFFICIENT & T-STATISTIC & P-VALUE \\
\hline Constant & - & 6.461 & .000 \\
Age & 0.049 & .890 & .374 \\
Sex & -.024 & -.491 & .624 \\
Marital status & -.037 & -.745 & .457 \\
Number of children & .049 & .848 & .397 \\
Level of education & .069 & 1.408 & .160 \\
Non-financial services & .359 & 7.179 & .000 \\
\hline
\end{tabular}

F-statistic $=12.453, \mathrm{p}$-value $=000$, Adjusted $\mathrm{R}^{2}=0.223$

Source: Field survey, 2012

From table 5, it was observed that marital status, sex, age, number of children and level of education of clients of SAT do not have statistically significant relationship with their human capital development. Although number of children, age and level of education have positive coefficients they are not significant. This compares favourably with the studies by Adjei, Arun and Hossain (2009) about how educational levels did not produce much differing impacts on human capital development of clients of microfinance institutions. Sex and marital status rather had negative significance, an indication that they are not exceptional in initiating human capital development.

In contrast, non-financial services provided by SAT had a positive and significant relation with human capital development. The co-efficient of 359 suggests that non-financial services explain about 36 percent variation in the human capital development of SAT clients. A main reason could be that clients became regularly acquainted with SAT staff and group members for sensitisation programmes aimed at fostering human capital development.

Further interviews and rating by respondents on the effects of non-financial services on the human capital development of clients and their families corroborated the statistical analysis. For example, 115 out of the 361 respondents (representing 31.9\%) rated the effects of the non-financial services on human capital development as high (see figure 2). Further 108 respondents (29.9\%) gave a fairly high rating while 50 respondents (13.9\%) rated it as high. However, $11(3.0 \%)$ respondents and a further $77(21.3 \%)$ rated the effects of the non-financial services as very low and low respectively. Respondents indicated that the non-financial services including book keeping, training, awareness raising have improved their human capital in three main ways: enhanced knowledge, enhanced skills for business management and enhanced health power.

Research participants explained how the non-financial services have enabled them to build their capacities in business management and record keeping. For example, a female focus group discussant stated that: "Before SAT services, I did not have adequate skills in separating my business incomes and overall expenditures. It was therefore difficult for me to track my actual incomes and I felt my monies and for that matter my income was being 'spirited' away by some unseen forces. With education from SAT officers on book keeping, basic accounting and prudent uses of my money, I have been able to sort out my incomes from other monies". Respondents further made references to how the non-financial services has enabled them to invest in training and apprenticeships of family members which have built their human capital. As a participant narrated during one of the focus group discussions: "yen mma nti na yerebere yi, won daakye ntria" meaning that we are working very hard because of our children, we want to invest in our children to do well in the future. SAT officers encourage and give us all the support we need". Respondents further indicated that awareness raising and encouragement from loan officers have enabled them to acquire and renew National Health Insurance Scheme (NHIS) cards. In Ghana, NHIS cards allow subscribers to access medical services at no cost at the point of needs (Arhin, 2013). Others also talked about how health education from SAT had enabled them to reduce the incidence of malaria in their homes. Thus, consistent with the observation by Mahjabeen (2008), the non-financial services are improving the human capital development of the clients through enhanced skills, knowledge and improved access to health services. 


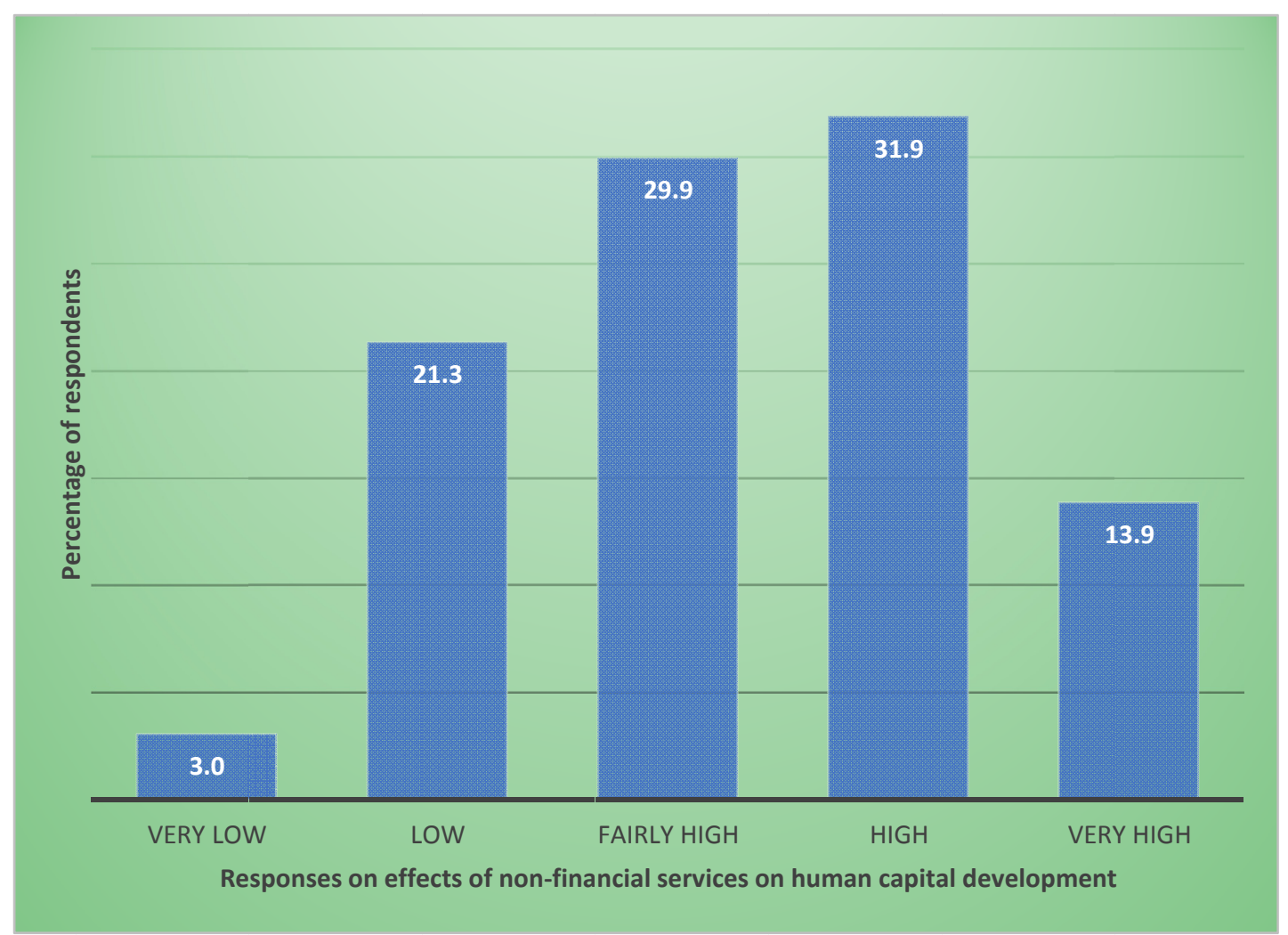

Figure 2. Rating of contribution of non-financial services to human capital development of clients

Source: Field survey, 2012

The foregoing discussion lends credence to the growing evidence suggesting that human capital development remains one of the essential channels through which microfinance helps to reduce poverty and provide value to clients (Mosley and Roch, 2004). This study has advanced this observation and showed that it is not only financial services (i.e. loans) that impact on human capital. Instead, the non-financial services equally help to improve the human capital development of clients. From the ongoing analysis, non-financial services such as basic bookkeeping, personal financial management training, skill development, sensitization programmes and social organizations offered by SAT as part of its microfinance package was significantly contributing to the human capital development of the clients.

\section{Discussion, Policy Implications and Conclusion}

This paper set out to examine whether non-financial services of microfinance schemes have effects on human capital development. As the analysis above shows, Non-financial services offered by SAT had positive significance on human capital development of the clients. Human capital development has been identified as one of the key determinants of growth and poverty alleviation, and also for the attainment of the globally agreed Sustainable Development Goals (UN, 2015; Arouri, 2014). Recent influential reports on microfinance and the SDGs by the Consultative Group to Assist the Poor (CGAP, 2016) have focused largely on core services of microcredits, microsavings and microinsurance and how these services enhance financial inclusion. Yet, as this study has highlighted, a focus on the non-financial services can also play a crucial role in advancing human capital development in the context of the 2030 Sustainable Development Agenda. This calls for the need for broadening the discourse on the interlinkages between microfinance and human capital development in the context of the post-SDG world.

There are at least two main channels through which a greater focus on non-financial services offered by MFIs can contribute to human capital development to advance the SDGs. First, non-financial services of MFIs increase education and skills building for clients and their families. As the preceding section revealed, some of the non-financial services have enabled clients to build their capacities in business management and record keeping and has enhanced their knowledge on better management of the loans and financial services received. Enhanced 
knowledge on better management of loan reduces risk of default and can further contributes to poverty reduction (SDG 1); The research has also shown that enhanced knowledge from the series of training organized by SAT has enabled the clients to invest in training and apprenticeships of family members, which is an important pathway for ensuring access to education for clients and families. Thus, the non-financial services such as the business management skills, record keeping, and the likes offered further enhance lifelong learning (SDG 4) that can create further opportunities for the clients. Second, the non-financial services can also help to increase access to health and other essential services that can improve the wellbeing of clients and their families (SDG 3). This has been evidenced in how the SAT services have enabled respondents to have increased awareness on prevalent diseases such as malaria as well as enhanced ability to renew health insurance cards-which is the main prerequisite for accessing affordable healthcare in Ghana. The findings contained in this paper therefore have important implications for both microfinance institutions as well as clients. For microfinance institutions, the study shows how additional services such as training could help clients to maximise the value from microfinance schemes. For clients, the study draws attention to the need for them to take non-financial services offered by microfinance institutions seriously to improve on their own human capital development. The study also has policy implications as it builds an empirical evidence for the need for policy to encourage microfinance schemes to integrate non-financial services to their traditional focus of providing only loans.

Despite these implications, the study has limitations. The main limitation related to the geographical scope of the study which was limited to one region, considering the fact that Sinapi Aba Trust programme has a national coverage. The choice of one region as study area indicates a limitation in terms of size and composition of sample size. This may affect generalisation of the study results. However, despite the limitations the results offer important insights on how microfinance non-financial services might be used as a tool in advancing the Sustainable Goals, particularly those related to poverty reduction, life-long learning, and improved well-being.

\section{References}

Adjei, J. K., Arun, T., \& Hossain, F. (2009). The role of microfinance in asset -building and poverty reduction: The case of Sinapi Aba Trust of Ghana. Brooks World Poverty Institute Working Paper Series, 84. The University of Manchester, United Kingdom.

Afrane, S. (2002). Impact Assessment of Microfinance Interventions in Ghana and South Africa: A synthesis of Major Impacts and Lesasons. Journal of Microfinance, 4(1), 37-58.

Antoh, E. F., Mensah, J. V., \& Edusah, S. E. (2014). The Effect of Microfinance on Human Capital Development in Ghana: The Case Of Sinapi Aba Trust Microfinance Clients In Ashanti Region. The International Journal of Social Sciences and Humanities Invention, 2(08).

Arhin, A. A. (2013). Promising Start, but bleak future? Progress of Ghana's National Health Insurance Schemes towards Universal Health Coverage. Developing Country Studies, 3(13), 151-159.

Arouri, M., Ben Youssef, A., Durairaj, V., Dahmani, M., \& Mungomba, N. (2014). Microfinance: A powerful Tool for Human Development in Africa. In A. Soucat, \& N. Mthuli (Eds.), One Billion People, One Billion Opportunities (Chapter 26). African Development Bank. Tunis.

Barnes, C., Keogh, E., \& Nemarundwe, N. (2001). Microfinance Program Clients and Impact: An Assessment of Zambuko Trust Zimbabwe. Washington, DC: Assessing the Impact of Microenterprise Services.

Beach, M. J. (2009). A critique of human capital formation in the U.S. and the economic returns to sub-baccalaureate credentials. Educational studies. A Journal of the American Educational Studies, 45(1), 24-38. https://doi.org/10.1080/00131940802562313

Becker, G. S. (1964). Human capital: theoretical and empirical analysis, with special reference to education. New York: National Bureau of Economic Research.

Claessens, S., \& Tzioumis, K. (2006). Measuring firms' access to finance. World Bank, 1-25.

Crisp, R. J., \& Turner, R. N. (2007). Essential social psycholog. London: SAGE Publication.

De la Cruz, N., Crookston, B., Gray, B., Alder, S., \& Dearden, K. A. (2009). Microfinance against Malaria: Impact of Freedom from Hunger's Malaria Education When Delivered by Rural Banks in Ghana. Transactions of the Royal Society of Tropical Medicine and Hygiene, 103(12), 1229-36. https://doi.org/10.1016/j.trstmh.2009.03.018

Dunford, C. (2002). Building Better Lives: Sustainable Integration of Microfinance with Education in Child Survival, Reproductive Health, and HIV/AIDS Prevention for the Poorest Entrepreneurs. In Pathways Out of Poverty: Innovations in Microfinance for the Poorest Families, ed. Sam Daley-Harris, 75-132. 
Bloomfield, CT: Kumanian Press.

Duvendack, M., Palmer-Jones, R., Copestake, J. G., Hooper, L., Loke, Y., \& Rao, N. (2011). What is the evidence of the impact of microfinance on the well-being of poor people.

Fischer, G., \& Ghatak, M. (2010). Repayment frequency in microfinance contracts with present-biased borrowers before World War I. Social Science Working Paper, No.1016, California Institute of Technology.

Ghalib, A. K. (2009). Measuring the impact of microfinance intervention: a conceptual framework of social impact assessment. IARC working papers series no. 24.

Ghana Statistical Service. (2006). Pattern and trends of poverty in Ghana (1991-2006). Accra: GSS.

Ghana Statistical Service. (2008). Ghana Living Standards Survey Report of the Fifth Round (GLSS 5). Accra: GSS.

Ghana Statistical Service. (2012). 2010 Population and housing census: Summary report of final results. Accra: GSS.

Ghana Statistical Service. (2014). Ghana Living Standards Survey Round 6: Labour Force Report. Accra, Ghana: Ghana Statistical Service. Retrieved from http://www.statsghana.gov.gh/docfiles/glss6/GLSS6_Labour\%20Force\%20Report.pdf

Ghana Statistical Service. (2016). 2015 Labour Force Report. Accra, Ghana: Ghana Statistical Service. Accra, Ghana: Ghana Statistical Service. $\quad$ Retrieved from http://www.statsghana.gov.gh/docfiles/publications/Labour_Force/LFS\%20REPORT_fianl_21-3-17.pdf

Government of Ghana. (2010). Medium-Term National Development Policy Framework, Ghana Shared Growth and Development Agenda GSGDA, 2010-2013, Accra: Government of Ghana and National Development Planning Commission NDPC.

Gupta, G. R., \& Malhotra, A. (2006). Empowering women through investments in reproductive health and rights. International centre for research on women ICRW. Prepared for the David and Lucile Packard Foundation Population Programme Review Task Force, January 2006. Retrieved from $\mathrm{http} / / /$ www.packard.org/assets/files/population/programme\%20review/pop_rev_gupta.pdf

Hamada, M. (2010). Financial services to the poor: An introduction to the special issue on microfinance. The Developing Economies, 48(1), 1-14. https://doi.org/10.1111/j.1746-1049.2010.00097.x

Kanbur, R., \& Squire, L. (2001). The evolution of thinking about poverty: exploring the interactions. Frontiers of development economics: The future in perspective, 183-226.

Khandker, R. S. (2005). Microfinance and poverty: Evidence using panel data from Bangladesh. The World Bank Economic Review, 19(2), 263-286. https://doi.org/10.1093/wber/lhi008

Khavul, S. (2010). Microfinance: Creating Opportunities for the Poor? Academy of Management, 24(3), 58-72.

Klapper, L., El-Zoghbi, M., \& Hess, J. (2016). Achieving the Sustainable Development Goals, The Role of Financial Inclusion: Consultative Group to Assist the Poor.

Langelett, G. (2002). Human capital: A summary of the 20th Century Research. Journal of Education Finance, $1(28), 1-23$.

Leatherman, S., \& Dunford, C. (2010). Linking Health to Microfinance to Reduce Poverty. Bulletin of the World Health Organisation, 88(6), 470-471. https://doi.org/10.2471/BLT.09.071464

Mahjabeen, R. (2008). Micro financing in Bangladesh: Impact on households, consumption and welfare. Journal of Policy Modelling, 30, 1083-1092. https://doi.org/10.1016/j.jpolmod.2007.12.007

Maldonado, J. H., González-Vega, C., \& Romero, V. (2003). The influence of microfinance on human capital formation: evidence from Bolivia. Paper presented at the seventh annual meeting Latin, American and Caribbean Economics Association (LACEA) Madrid, Spain.

Martin, I., Hulme, D., \& Rutherford, S. (1999). Financial services for the poor and poorest: deepening understanding to improve provision, finance and development research program. Working Paper series, no. 9. http:/hummedia.manchester.ac.uk/institutes/gdi/publications/workingpapers/archive/fd/fdwp09.pdf

Mayoux, L., \& Chambers, R. (2005). Reversing the paradigm: quantification, participatory methods and pro-poor impact assessment. Journal of International Development, 17(2), 271-298. 
https://doi.org/10.1002/jid.1214

Melzer, B. (2011). The real costs of credit access: Evidence from the payday lending market. The Quarterly Journal of Economics, 126(1), 517-555. https://doi.org/10.1093/qje/qjq009

Nader, Y. F. (2008). Microcredit and socio-economic well-being of women and their families in Cairo. Journal of Socioeconomic, 37(2), 644-656.

National Development Planning Commission (NDPC). (2008). Growth and poverty reduction strategy (GPRSII) 2006-2009. Annual Progress Report, Accra: NDPC.

National Development Planning Commission NDPC. (2008). Growth and poverty reduction strategy (GPRSII) 2006-2009. Annual Progress Report, Accra: NDPC.

NDPC. (2010). Ghana Shared Growth and Development Agenda (GSGDA, 2010-2013). Retrieved from http://www.un-page.org/files/public/gsgda.pdf

Odell, K. (2010). Measuring the impact of microfinance: Taking another look. Washington, DC: Grameen Foundation.

Pronyk, P. M., Kim, J. C., Abramsky, T., Phetla, G., Hargreaves, J. R., Morison, L. A., ... Porter, J. D. H. (2008). A Combined Microfinance and Training Intervention Can Reduce HIV Risk Behaviour in Young Female Participants. AIDS, 22(13), 1659-65. https://doi.org/10.1097/QAD.0b013e328307a040

Republic of Ghana and UNDP. (2015). Ghana Millennium Development Goals, 2015 Report. Retrieved from http://www.gh.undp.org/content/dam/ghana/docs/Doc/Inclgro/UNDP_GH_2015\%20Ghana\%20MDGs\%20 Report.pdf

Robinson, M. S. (2001). The microfinance revolution: Sustainable finance for the poor. Washington D.C: The World Bank: Open Society Institute. https://doi.org/10.1596/0-8213-4524-9

Sarantakos, S. (2005). Social Research (3rd ed.). Hampshire: Palgrave Macmillan. https://doi.org/10.1007/978-0-230-20901-5

Schultz, T. P. (1993). Investments in the schooling and health of women and men: quantities and return. Journal of Human Resources, 28(4), 694-734. https://doi.org/10.2307/146291

Schultz, T. W. (1961). Investments in human capital. American Economic Review, 51(1), 1-17.

Sswamala, F. M., Ismayilova, L., McKay, M., Sperder, E., Bannon, W. Jr., \& Alicea, S. (2010). Gender and the Efects of an Economic Empowerment Program on Attitudes toward Sexual Risk-Taking among AIDS-Orohaned Adolescent Youth in Uganda. Journal of Adolescent Health, 46(4), 372-378. https://doi.org/10.1016/j.jadohealth.2009.08.010

Yunus, M. (1999). Banker to the Poor: Microlending and the Battle Against Poverty. New York: Public Affairs.

Yunus, M. (2003). Expanding microcredit outreach to reach the millennium development goal: Some issues for attention. Retrieved February 13, 2009, from http://www.microfinancegateway.org/files/3642_Yunus3.doc

\section{Copyrights}

Copyright for this article is retained by the author(s), with first publication rights granted to the journal.

This is an open-access article distributed under the terms and conditions of the Creative Commons Attribution license (http://creativecommons.org/licenses/by/4.0/). 